\title{
An Interdisciplinary Environmental Education Approach: Determining the Effects of E-STEM Activity on Environmental Awareness
}

\author{
Sevcan Candan Helvaci ${ }^{*}$ İsmail Helvaci \\ Faculty of Education, Kastamonu University, Turkey
}

Copyright $(2019$ by authors, all rights reserved. Authors agree that this article remains permanently open access under the terms of the Creative Commons Attribution License 4.0 International License

\begin{abstract}
In addition to the studies conducted regarding STEM (Science, Technology, Engineering and Mathematic), which is a new approach in education and attract attention worldwide, researches also concentrated on the effectiveness of the partnership of this interdisciplinary approach with other disciplines. The aim of this study is to determine the effect of an education carried out with an E-STEM activity on the environmental awareness of students and their opinions on E-STEM disciplines. In the study, a holistic multi-state pattern was used among the case study patterns. Data obtained from semi-structured interview and activity plans were analyzed using content analysis. There were 18 participants in the study conducted at a centralized public school in a province located in western Black Sea Region of Turkey, who were at 6th grade in the 2017-2018 Academic Year. The E-STEM activity prepared within the scope of the application was implemented for a total of 6 course hours for three weeks. At the end of the study, in the light of the information obtained from the participants who provide opinions on STEM disciplines, environmental awareness sub-dimensions and E-STEM, it was determined that the application had positive effects. Participants made positive statements about the environment, especially on recycling, and the use of the different disciplines together. Based on this research, it was suggested that it would be useful to develop studies on E-STEM.
\end{abstract}

Keywords STEM, E-STEM, Interdisciplinary Education, Environmental, Environmental Education, Primary Education

\section{Introduction}

Individuals have the inherent desire to add new ones to their existing knowledge and to achieve better results. In line with this request, the expected requirements are designated on the basis of being able to develop suggestions aimed to solve problems, and as for the suggestions developed, having creative, critical thinking ability and design ability [1-2]. This basis is the motive for the education systems to change, develop and search for the best continuously. Such competition environment being experienced at international level leads countries to focus on targeting modernism in science, engineering and technology and on using different disciplines all together [3].

The use of different disciplines in education all together is not a new concept and a great deal of practices have been carried out in this field, besides, it is know that such multidisciplinary approach plays a major role in the development of advanced thinking skills [4-5-6-7]. Interdisciplinary approaches and practices based on this approach enable the use of more than one discipline in the solution of complex problems [5]. STEM is one of the newest approaches related to the use of different disciplines together. STEM is an acronym for the disciplines of Science, Technology, Engineering and Mathematic. Judith A. Ramaley, director of The National Science Foundation, was the person who introduced STEM approach to education literature for the first time [8]. This approach is considered as a key to create a progressive society in especially the United States, and also in China, Japan, Korea and most of the European Union countries [9]. Studies carried out with STEM disciplines aim to provide a development for individuals in reaching new information [10-11].

In today's world, the tendency of the countries to run against each other to create original products and progress in technology has also an effect on education as well [3]. This orientation, which comes into prominence in order to educate individuals having the skills of the 21 st century, has also manifested itself through the changes in curriculums. In 2018, our national science education has been changed on an interdisciplinary basis and a new 
curriculum has been started to be used on the basis of STEM approach [3]. The collective use of Science and Engineering disciplines in the new curriculum, which is structured with STEM is also seen in the activities in the textbooks.

An education given on the basis of STEM aims to provide students with the ability to identify problems by using STEM disciplines on this basis, to offer solutions regarding the problems, to be able to reach new information along with the development and awareness towards the extent of STEM approach and how it can guide our surroundings [10-11]. STEM is an approach that covers the whole education process of the individuals from pre-school to higher education, rather than just covering a certain part of the education period [12]. In this context, from the point of view that STEM is an approach that spreads through the whole education process, it is required to develop educational policies and curriculums considering the needs of the country within the scope of entrepreneurship (STEM-Entrepreneurship, STEM+E), art/design (STEM-Art, STEAM) and computing (STEM-Computing, STEM+C) [13]. One of the versions of the STEM approach adapted to the conditions of the 21st century is E-STEM (Environmental, Science, Technology, Engineering and Mathematic) which is formed by integrating the environment into STEM disciplines. The E-STEM concept was introduced by National Association for Environmental Education. Under the title of Engaging Young People in 21st Century Community Challenges: Linking Environmental Education with Science, Technology, Engineering \& Math, it provides information on combining STEM and Environmental education disciplines [14]. When the studies on STEM approach are examined, it is seen that STEM deals with determining the needs of the future by taking reference from today and being able to take measures for such needs. From this point of view, analyzing the environment-oriented need-measure relationship on the basis of E-STEM has a structure that will lead to a more solid perspective to the environmental consciousness.

The Science Curriculum implemented in Turkey includes contents about environment in each grade especially at middle school level. Acquisitions about environment are concentrated in the units that are under the "Living Beings and Life" subject area. Contents and acquisitions about environmental consciousness are concentrated in the Human and Environment unit in the $4^{\text {th }}$ and $5^{\text {th }}$ grades [3]. The special purposes of the curriculum make references to environmental sciences, individual-society-environment interactions, wonder about the nature and immediate environment, and skill to offer solutions to the problems encountered. When the Science curriculum is examined within the context of environment, it is seen that although it is adequate in terms of the intensity of contents and acquisitions, it is inadequate especially in terms of STEM-based environmental education activities relevant to the curriculum structure.
Though the curriculum structure is suitable, textbooks do not include a clear activity involving collective use of STEM and environmental disciplines.

The aim of this study is to determine the effect of an education conducted with E-STEM activities that enable the use of the disciplines of Environmental, Science, Technology, Engineering and Mathematic. Upon reviewing the literature, it is noted that even though there were studies using STEM, STEAM approaches [15-16-17-18-19-20-21-22], the quantity of studies provided using E-STEM approach was not sufficient. This is also the same for the quantity of the enlightening studies regarding the structure of E-STEM studies. In the light of this information, it is expected that the study will contribute to the subject matter. This study is considered to be valuable since it is among the study cases where STEM studies blend with different disciplines The research problem is determined as follows:

What is the effect of the E-STEM activity carried out in Secondary School, 6th grade, on environmental awareness and opinion on E-STEM disciplines of 6th grade students? What are the opinions of the 6th grade students regarding the process of the application?

\section{Materials and Methods}

In this study, which was conducted as a qualitative research, a holistic multi-state pattern was used among the case study patterns [23]. Case studies provide an in-depth investigation of an event that took place [24]. Within this framework, the case can be an individual/individuals (separately or as a group), a program, incidents or activities, a process, an unusual event or a specific problem [25]. In this study, it will be aimed to determine the relationship of the Environmental discipline provided along with STEM approach with all other disciplines in addition to environmental awareness, and all these will be addressed in a holistic manner.

\section{Study Group}

In the selection of the participants, convenient sampling and criterion sampling methods were used among purposeful sampling methods [26]. The study group consisted of 18 6th grade students receiving education in a public school during the 2017-2018 Academic Year, in a province located in the West Black Sea Region. 10 of the participants were female and 8 were male. Participants were included in the study with ordered codes such as S1, $\mathrm{S} 2, \ldots$

\section{Data Collection Tools}

The semi-structured interview form drawn up by the researchers was used in the study. In the semi-structured interview form, there are 4 questions aimed to obtain 
opinions regarding STEM and the Environment, and 2 questions in order to determine views on the application. While the first four questions were asked in the interviews that took place before and after the application; as for 2 interview questions specifying the opinions on the application, the data were collected only at the end of the practice.

\section{Analysis of Data}

Data obtained from the interview forms were analyzed by content analysis method. Content analysis is the process of summarizing and defining the basic contents of the available written documents [27]. In the content analysis, there are four stages including processing of qualitative research data obtained from documents, coding of data, finding themes, arranging codes and themes, and identifying and interpreting the findings [24]. For the first step, the interview forms have been put into writing in computer environment without making any changes. A total of 28 pages of written documents were obtained; there were 7 pages before the application took place and 21 pages after it is completed. Interview data transcribed without making any changes is cleared from the daily spoken language [28-29]. Afterwards, the interview was rearranged according to documenting rules [30]. A program called Nvivo was used in the analysis of the transcribed interview records. The data were analyzed by inductive analysis. The data obtained were read independently by the researchers and individual codes and categories were created. These individually generated codes and categories are compared, and the records were examined until a consensus was reached. The agreement percentage formula among the individual data solutions suggested by Miles and Huberman (1994) was used in order to determine the reliability of the study. The agreement percentage is calculated as follows: Agreement Percentage $=($ Consensus $) /($ Consensus + Dissidence $) \mathrm{X}$ 100. Agreement percentage was calculated as 94.43. For each research problem, coding and categorization were done before and after the application, and findings were presented including references.

\section{Application Process}

The application continued for 3 weeks as part of the
2017-2018 Science Course. 2 course hours were allocated for the application per week, and the application lasted 6 course hours in total. The participants were divided into groups of three persons and there were 6 groups in total. Voluntary participation of individuals in groups was taken into account while forming the groups. They were asked to find a group name representing their groups with the aim of increasing the efficiency of the study and sense of belonging. In order to ease the progress of activities, special boxes called activity boxes were prepared for each group, containing activity plans and activity materials. Boxes are customized by typing the group names on the activity boxes. In the first week of the application, the individuals perceived the problem, and within the same week, participants were asked to produce ideas that embody the consideration of what to do regarding the problem. Groups have been given time to plan and do research. Activity boxes prepared were distributed among the groups. At the end of both course hours, the students were asked to place the prepared models in their current states in the activity boxes in order to continue in the following week, and they were allowed to continue with the models the following week. At the end of this process, which was repeated for three weeks, opinions of the participants were obtained regarding E-STEM application and environment.

In the activity used in the application, an activity that provides interdisciplinary work was planned in the perspective of the subject of Wastes and Recycling (Appendix 1). In the activity, the following disciplines were used; Science in using the contents of the learning area of Living Beings and Life; Mathematics in mathematical calculations; Engineering as a result of the structure of the created model and Technology in digital recording of the collected waste. Furthermore, it was focused on 5R (Refuse, Reduce, Reuse, Repair, Recycle) which sloganizes recycling.

\section{Findings}

Table 1 and Table 2 show the analysis of the statements of participants about environmental knowledge, attitude and behavior, which are sub-dimensions of environmental consciousness.

Table 1. Before Application Number of References and Coding Density of the Participants' Opinions on Environmental Consciousness

\begin{tabular}{|c|c|c|c|c|}
\hline Category & Code & $\begin{array}{l}\text { Number of } \\
\text { References }\end{array}$ & $\begin{array}{c}\text { Coding Density } \\
(\%)\end{array}$ & $\begin{array}{c}\text { Coding Density } \\
(\%)\end{array}$ \\
\hline \multirow{3}{*}{$\begin{array}{l}\text { Environmental } \\
\text { Knowledge }\end{array}$} & Smoking & 7 & 23,3 & \multirow{3}{*}{80} \\
\hline & Air pollution & 6 & 20,0 & \\
\hline & Waste & 11 & 36,7 & \\
\hline \multirow{2}{*}{$\begin{array}{l}\text { Attitude towards } \\
\text { environment }\end{array}$} & $\begin{array}{l}\text { React to those throwing } \\
\text { garbage }\end{array}$ & 3 & 10,0 & \multirow[t]{2}{*}{20} \\
\hline & Love for trees & 3 & 10,0 & \\
\hline
\end{tabular}


Table 2. After Application Number of References and Coding Density of the Participants' Opinions on Environmental Consciousness

\begin{tabular}{|c|c|c|c|c|}
\hline Category & Code & $\begin{array}{l}\text { Number of } \\
\text { References }\end{array}$ & $\begin{array}{c}\text { Coding Density } \\
(\%)\end{array}$ & $\begin{array}{c}\text { Coding Density } \\
(\%)\end{array}$ \\
\hline \multirow{3}{*}{ Environmental Knowledge } & Recycling & 17 & 11 & \multirow{3}{*}{33,1} \\
\hline & Types of Waste & 16 & 10,4 & \\
\hline & Law reducing the use of Plastic Bags & 18 & 11,7 & \\
\hline \multirow{4}{*}{$\begin{array}{l}\text { Positive attitude towards the } \\
\text { environment }\end{array}$} & Happiness due to clean environment & 11 & 7,2 & \multirow{4}{*}{32,6} \\
\hline & $\begin{array}{l}\text { Willingness towards } 5 \mathrm{R} \text { to become } \\
\text { widespread }\end{array}$ & 15 & 9,7 & \\
\hline & React to those throwing garbage & 13 & 8,5 & \\
\hline & Future Anxiety & 11 & 7,2 & \\
\hline \multirow{5}{*}{ Useful Behavior } & Making a Recycle Bin & 13 & 8,4 & \multirow{5}{*}{34,3} \\
\hline & Separation of the wastes & 10 & 6,5 & \\
\hline & Garbage collection & 9 & 5,8 & \\
\hline & $\begin{array}{l}\text { Using a model designed for garbage } \\
\text { collection }\end{array}$ & 13 & 8,4 & \\
\hline & Raising Awareness / Warning & 8 & 5,2 & \\
\hline
\end{tabular}

When Table 1 and Table 2 are examined, it is seen that there are differences in the participants' statements regarding knowledge, attitude and behavior towards environment as per the statements obtained before and after the application. When the coding densities obtained from the statements of the participants before the application are listed; it is observed that waste, smoking and air pollution was mentioned in the environmental knowledge category, and their dislike towards those who throw garbage and their love for trees were mentioned in the category of positive attitude towards the environment. It was determined that some of the participants considered smoking as the cause of environmental pollution (especially air pollution). When participants using these statements were asked about the reasons of their opinions, they stated that they had seen this information in public service announcements, which was regularly included in television broadcasts as a deterrent for smoking. Sample statements of the individuals expressing such statements are as follows:

"The environment is polluted by smokers [=smoking]." "When I look outside from the school bus, I see smokers [= smoking], they pollute the air [=air pollution]." (Pre-Application Interview S2)

"On TV, in advertisements, smokers cannot breathe and they die due to air [= air pollution]" (Pre-Application Interview S11)

When the opinions of the participants are examined after the application, it is seen that in the environmental knowledge category, there are references to recycling, waste types and to the law aimed at reducing the use of plastic wastes that will come into force in our country. They had a positive attitude towards the environment as per their statements in the attitude category. Participants had the feeling of happiness for clean environment, reaction to those throw garbage, concern for the future of the environment and willingness towards waste reduction and towards $5 \mathrm{R}$ to become widespread which the slogan of recycling. Sample statements of the individuals expressing such statements are as follows:

"Bag is plastic and we should not throw it in the same bin with the fruit peel [= waste types]", "Bags can be collected and made into plastic again [= recycling]", "They are throwing the bags onto the streets... It will be very nice that the bags will be banned in markets [= Law reducing the use of Plastic Bags]", "Fewer bags will be garbage." (Post-Application Interview S5)

"I feel happy when there is no garbage around [= happiness towards clean environment] and I certainly cannot stand a person throwing garbage [ $=$ react to those throwing garbage]" (Post-Application S1)

Examining the post-application statements of the participants regarding positive attitude towards the environment, it is seen that the coding density was mostly for the designed model. It is also noted that the idea of carrying out concrete actions against the environment was formed as a result of the model built within the scope of the study. The Participants also stated that they built a recycle bin, grouped and stored waste in these bins and made people around them conscious with the model they designed. Sample statements of the individuals expressing such statements are as follows:

"I took my garbage collecting hand out of my bag and dumped the trash which was on the floor into our boxes [= making a recycle bin] [using a model designed for garbage collection], [= garbage collection]." "Those who have seen my hand liked it so much, they liked its colors, I told and taught them, and told them why they should do the same as well [= raising awareness/warning]." (Post-Application Interview S18)

The views of the participants on the E-STEM disciplines and their views on application are given in Table 3. 
Table 3. Number of References and Coding Density of the Participants' Opinions on E-STEM

\begin{tabular}{|c|c|c|c|c|}
\hline Category & Code & $\begin{array}{l}\text { Number of } \\
\text { References }\end{array}$ & $\begin{array}{l}\text { Coding } \\
\text { Density } \\
(\%)\end{array}$ & $\begin{array}{l}\text { Coding Density } \\
(\%)\end{array}$ \\
\hline \multirow{5}{*}{$\begin{array}{l}\text { Views on E-STEM } \\
\text { Disciplines }\end{array}$} & Increased awareness regarding STEM & 12 & 13,6 & \multirow{5}{*}{46,6} \\
\hline & $\begin{array}{l}\text { The thought of the effectiveness of using } \\
\text { environment and STEM disciplines together }\end{array}$ & 13 & 14,8 & \\
\hline & The desire to become an engineer & 5 & 5,7 & \\
\hline & $\begin{array}{l}\text { Willing to build a professional version of the } \\
\text { model }\end{array}$ & 7 & 8,0 & \\
\hline & The idea that the model can be sold/purchased & 4 & 4,5 & \\
\hline \multirow{3}{*}{$\begin{array}{l}\text { Views on the } \\
\text { Application Process }\end{array}$} & Enjoying the activity & 16 & 18,2 & \multirow{3}{*}{53,4} \\
\hline & Enjoying the model and the tendency to store it & 14 & 15,9 & \\
\hline & Desire to carry out similar activities & 17 & 19,3 & \\
\hline
\end{tabular}

Examining Table 3, which includes the views of the participants on the application process and E-STEM disciplines, it is seen that there is a positive development regarding E-STEM disciplines. It is noted that they have an idea about each discipline of STEM and understand the effect of using these disciplines together. At the end of the activity, participants wanted to be an engineer and they wanted to build a professional version of the model. Some of the participants stated that they could sell the model they designed if they were made of durable material, and that individuals might want to buy this model. When the views on the application process are examined, it is seen that the participants are affected positively by the whole process. They liked the activity and were willing to do similar activities. In addition, the students stated that they liked the model they designed and would like to keep their models. These references regarding their desire to keep the models were found to support the positive attitudes towards the process.

"I worked like an engineer. I felt so good [= liking/enjoying the event]. I always want to do stuff like this $[=$ Desire to carry out similar activities]." (Post Application S7)

"I used science, mathematics, engineering, and technology for the environment [The thought of the effectiveness of using environment and STEM disciplines together]. I've done calculations and I've paid attention to a lot of things to do the best [= Increased awareness regarding STEM]. I would design this model more robust if I could melt the iron [ $=$ Willing to build a professional version of the model]". (Post-Application S13)

\section{Conclusions}

The aim of this study was to determine the effects of the activity carried out, on knowledge, attitude and behavior sub-dimensions of environmental awareness, and the opinions regarding the application process within the scope of E-STEM approach, which introduces a new perspective to interdisciplinary approach. In this framework, the opinions of the participants were asked before and after the application. In the light of the findings obtained from the study, it was concluded that the application had a positive effect on the participants regarding E-STEM, E-STEM disciplines and application. This result coincides with the studies in the literature showing that STEM applications had developed a positive attitude [19-32-33-34-35].

When the findings of the effect of the application on environmental consciousness are examined, it can be said that there was a development at the level of knowledge and attitude dimensions after the application. It is observed that new statements were formed especially in the behavior dimension after the application. Before the application, participants who had a simpler knowledge and attitude started to mention 5R after the application, to react to those who throw garbage and to conduct concrete behaviors towards the environment. It is also noted that such tendency to conduct concrete behaviors were environmentally friendly behaviors. One of the valuable results obtained is that, it is determined that students tend to show useful behaviors in a very short period of time as a result of the model designed. The environmental discipline integrated into STEM contributed to the tendency to show useful behavior, which is the last condition of being environmentally conscious. It can be commented that E-STEM is useful on improving environmental awareness.

One of the striking results of the research is the statements indicating that air pollution was caused by smokers. Although smoking is one of the factors that affect human health, it can be interpreted as a sign of misconceptions that smoking is considered to be directly responsible for air pollution. In addition, the statements indicating that this information was obtained from the public service announcements shows that this subject should be thought in the age group of the participants with sub-details.

When the participants' opinions about E-STEM disciplines and the application were examined, it was determined that there was awareness towards the effectiveness of interdisciplinary education and an increase 
in knowledge towards STEM. Participants said that they felt like an engineer while participating in the activity. Upon this development, which can be interpreted as an increase of self-confidence, the idea that they can create professional versions of the model when the required opportunities are provided is an important result. An individual who feels that he/she is qualified would want to advance and develop, and the creativeness of such an individual would increase. This finding of the study is similar to the studies indicating that STEM applications increase scientific creativity [36]. It can also be seen that it is moved to a commercial dimension with the idea of some participants stating that the product might be sold. It is noted that there are developments within the scope of entrepreneurship field in the Science, Engineering and Entrepreneurship activities that was introduced into our science education life with the 2018 Science Program. This result is considered as one of the valuable results of the study as well. The participants liked the process and requested to be repeated.

Based on the results, it is seen that E-STEM is a field that needs to be reinforced by conducting more researches on it. E-STEM studies should be focused on. Art discipline, which introduces an aesthetic design-based understanding to STEM, is also a subject that could be collectively worked on together with E-STEM. Carrying out E-STEM studies on environmental issues other than wastes and recycling will enrich the literature. It is recommended that, among the activities of Science, Engineering and Entrepreneurship included in the textbooks, those that are within the chapters based on Environment be arranged within the scope of E-STEM.

\section{Appendix 1}

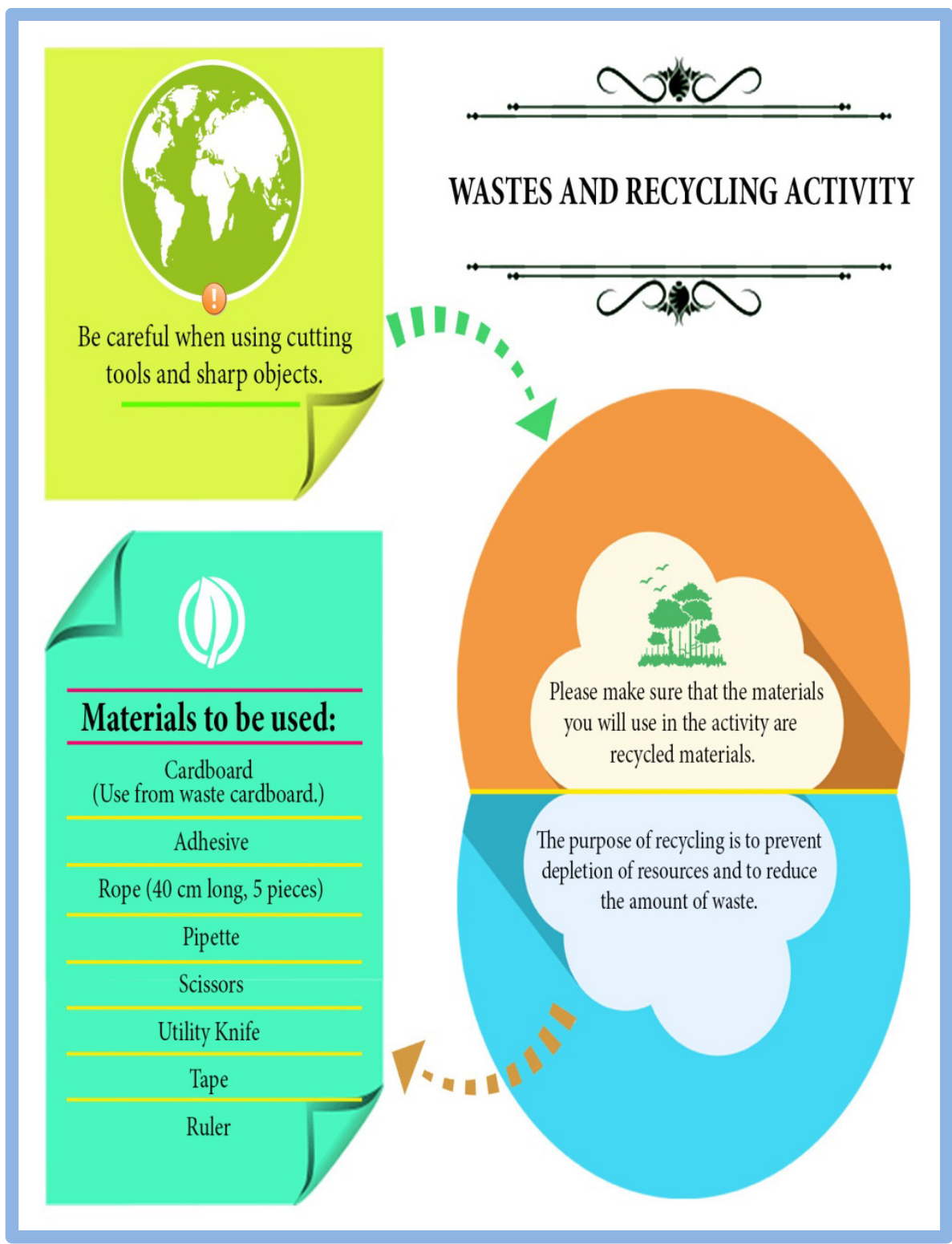


WASTES AND RECYCLING ACTIVITY APPLICATION STEPS STUDY SHEET

1. The scientific process begins with asking questions (with curiosity).

How does our hand model move?

What can be observed if our pipettes of hand model are attached on the reverse side?

2. There should be questioning in the scientific process.

0 Which features of our model can be changed?

0 What would be seen if the hand size of the model changes? Test the size variable by creating different sizes of the same shape.

0 What would be observed if the arm length of the model changes?

Test the length variable by creating different sizes of the same shape.

What would be observed if the pipette quantity in the hand part of the model changes?

Test the folding variable by creating different sizes of the same shape.

3. What scientific questionings did we perform in this activity?

4. How can we collect more garbage without changing our model? Improve your model by creating your own designs. Write down the features you developed.

5. Action is needed to protect the environment. What types of garbage could be collected with this model?

6. Which areas of $5 \mathrm{R}$ is this model in like with?

7. Can we use our model for enviroumental protection?

0 What did you feel while using this model?

What environmental questionings did we perform in this activity? 


\section{HOW TO MAKE}

1 Let's take the cardboard piece and cut it by drawing a hand model as shown in the figure. Each finger should be $10 \mathrm{~cm}$.

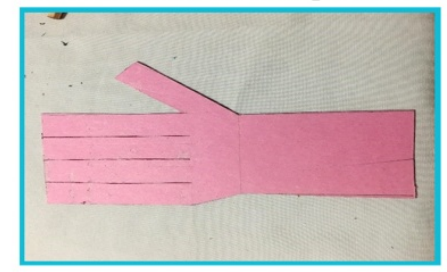

Let's examine our own hand and give our cartoon the shape of our knuckles

2 Then let's cut the pipette parts $3 \mathrm{~cm}$ long and attach them as shown. Attach 2 on the thumb, and 4 on the other fingers. Have $2 \mathrm{~cm}$ between each pipette piece. Let's pass the ropes through the pipettes.

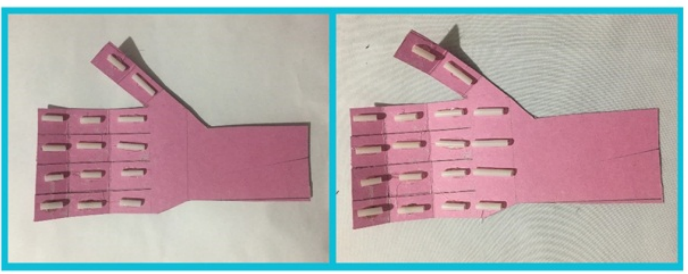

4 Now, as a second step, let's form the arm part. Arm length should be $20 \mathrm{~cm}$. Let's take our waste cardboard piece and create two rolls in such a way that they can pass through each other. And as shown in the figure, let's cut two holes in the sides of our rolls.

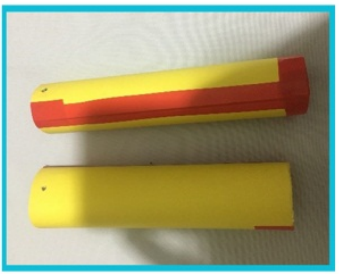

Let's take our rope and fasten it by connecting it to our roll piece which will be attached inside.

Then let's put the other piece on it and have the rope pass through its holes and fasten it. Our intertwining arm is ready.

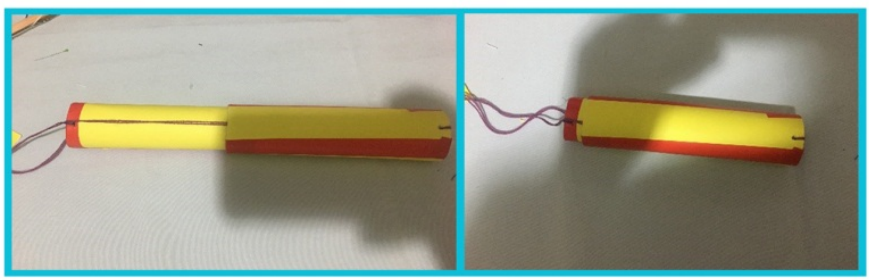

Let's fix our arm on our hand model. And our model is ready.

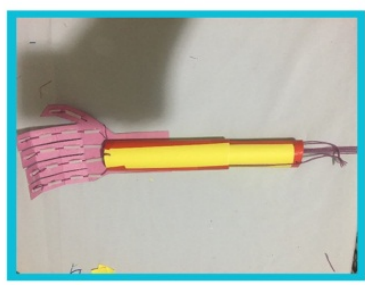

Let's pick up the waste we see in the classroom, in the school building and in the school yard with the help of this hand and throw them into the recycling bin. Let's sort the garbage according to their types and record them in our program.

Recycling protects natural resources and saves energy. It reduces the amount of waste and facilitates garbage storage. It prevents the pollution of air and environment. It prevents useful wastes from being wasted. It contributes to the economy. 


\section{REFERENCES}

[1] NRC (National Research Council) (2010). Exploring the intersection of science education and 21st century skills: A workshop summary. Washington, DC: National Academies Press.

[2] NRC (National Research Council) (2012). A Framework for k-12 science education: Practices, crosscutting concepts, and core ideas. Washington DC: The National Academic Press.

[3] Ministry of National Education (2018). Fen bilimleri dersi öğretim programı (ilkokul ve ortaokul $3,4,5,6,7$ ve 8 . siniflar). . Retrieved from http://ttkb.meb.gov.tr/www/gunc ellenen-ogretimprogramlari/icerik/151 [Accessed Dec 07 2018].

[4] Yıldırım, A. (1996). Disiplinler arası öğretim kavramı ve programlar açısından doğurduğu sonuçlar. Hacettepe Üniversitesi Eğitim Fakültesi Dergisi, 12, 89-94.

[5] Condee, W. F. (2004). The future is interdisciplinary. Teatre Survey, 2, 235-240.

[6] Haring, D. \& Kelner, T. (2015). Why we got serious about interdisciplinary teaching. Educational Leadership, 73(4), 68-72.

[7] Michelsen, C. (2015). Mathematical modeling is also physics-interdisciplinary teaching between mathematics and physics in Danish upper secondary education. Physics Education, 50(4), 489-494.

[8] Yıldırım, B. \& Altun, Y. (2018). STEM eğitimi Uüzerine derleme çalışması: Fen bilimleri alanında örnek ders uygulanmaları. M. Riedler et al. (Ed.) in VI. International Congress of Education Research 2014: Hacettepe University.

[9] Yılmaz, H., Koyunkaya, M. Y., Güler, F., \& Güzey, S. (2017). Fen, Teknoloji, Mühendislik, Matematik (STEM) eğitimi tutum ölçeğinin Türkçe'ye uyarlanması. Kastamonu Eğitim Dergisi, 25(5), 1787-1800.

[10] Bybee, R. W. (2010). Advancing STEM education: A 2020 vision. Technology and Engineering Teacher, 70(1), 30- 35.

[11] Bybee, R. W. (2011). Scientific and engineering practices in K-12 classrooms: Understanding a framework education. Science And Children, 49(4), 10-16.

[12] Corlu, M. S., Capraro, R. M., \& Capraro, M. M. (2014). Introducing STEM education: Implications for educating our teachers in the age of innovation. Education and Science, 39(171), 74-85.

[13] Akgündüz, D., Aydeniz, M., Çakmakçı, G., Çavaş, B., Çorlu, M. S., Öner, T., \& Özdemir, S. (2015). A report on STEM Education in Turkey: A provisional agenda or a necessity?][White Paper]. İstanbul Aydın Üniversitesi: STEM Merkezi ve Eğitim Fakültesi. Retrieved from http://www.aydin.edu.tr/belgeler/IAU-STEM-Egitimi-Turki ye-Raporu-2015.pdf [Accessed Dec 07 2018].

[14] Fraser, J., Gupta, R., Flinner, K., Rank, S., \& Ardalan, N. (2013). Engaging young people in $21^{\text {st }}$ century community challenges: linking environmental education with science, technology, engineering and mathematics, newknowledge report. New York: New Knowledge Organization.

[15] Barrett, B. S., Moran, A. L., \& Woods, J. E. (2014). Meteorology meets engineering: An interdisciplinary STEM module for middle and early secondary school students. International Journal of STEM Education, 1(1), 1-6.

[16] Cotabish, A., Dailey, D., Robinson, A., \& Hughes, G. (2013). The effects of a STEM intervention on elementary students' science knowledge and skills. School Science and Mathematics, 113(5), 215-226.

[17] Lam, P., Doverspike, D., Zhao, J., Zhe, J., \& Menzemer, C. (2008). An evaluation of a STEM program for middle school students on learning disability related IEPs. Journal of STEM Education, 9(1-2), 21-29.

[18] Olivarez, N. (2012). The impact of a STEM program on academic achievement of eighth grade students in a South Texas middle school. Doctoral dissertation. Texas A\&M University, Corpus Christi, Texas

[19] Rehmat, A. P. (2015). Engineering the path to higher-order thinking in elementary education: A problem-based learning approach for STEM integration. Doctoral dissertation. University of Nevada, Las Vegas. UNLV Theses/ Dissertations/ Professional Papers/ Capstones. Paper 2497. Retrieved from http://digitalscholarship.unlv.edu/thes esdissertations [Access Dec 01 2018]

[20] Robinson, A., Dailey, D., Hughes, G., \& Cotabish, A. (2014). The effects of a science-focused STEM intervention on gifted elementary students' science knowledge and skills. Journal of Advanced Academics, 25(3), 189-213.

[21] Tenaglia, T. (2017). STEAM curriculum: Arts education as an integral part of interdisciplinary learning. Messiah College Curriculum and Instruction Research Project, Parkway.

[22] Y1ldırım, B. \& Selvi, M. (2017). An experimental research on effects of STEM applications and mastery learning. Journal of Theory and Practice in Education, 13(2), 183-210.

[23] Yin, R. K. (2003). Case study research design and methods. London: Sage Publications.

[24] Yıldırım, A. \& Şimşek, H. (2013). Sosyal bilimlerde nitel araştırma yöntemleri. Ankara: Seçkin Yayıncılık.

[25] Creswell, J. (2009). Research design: Qualitative and quantitative approaches ( $3^{\text {rd }}$ Edition). Thousand Oaks, CA: Sage Publications.

[26] Patton, M. Q. (2002). Qualitative research \& evaluation methods (3rd Edition). Thousand Oaks, CA: Sage Publications.

[27] Cohen, L.,Manion, L., \& Morrison, K. (2007). Research methods in education ( $6 \mathrm{t}^{\mathrm{h}}$ Edition). London: Routledge.

[28] Coolican, H. (2009). Research methods and statistics in psychology. (5th Edition). London: Hodder Education.

[29] Kvale, S. (1996). Interviews an introduction to qualitative research interviewing. Thousand Oaks, California: Sage Publications.

[30] Mayring, P. (2000). Nitel sosyal araştırmaya giriş (Çev. A. GümüĢ ve M. S. Durgun). Adana: Baki Kitabevi. 
[31] Miles, M. B. \& Huberman, A. M. (1994). Qualitative data analysis: An expanded sourcebook ( $2^{\text {nd }}$ Edition.). Thousand Oaks, California: SAGE.

[32] Baran, E., Canbazoğlu-Bilici, S., \& Mesutoğlu, C. (2015). Fen, teknoloji, mühendislik ve matematik (FeTeMM) spotu geliştirme etkinliği. Araştırma Temelli Etkinlik Dergisi (ATED), 5(2), 60-69.

[33] Gülhan, F. \& Şahin, F. (2016). Fen-teknoloji-mühendislik-matematik entegrasyonunun (STEM) 5. sınıf öğrencilerinin bu alanlarla ilgili alg1 ve tutumlarına etkisi. International Journal of Human Sciences, 13(1), 602-620.

[34] Tseng, K. H., Chang, C. C., Lou, S. J., \& Chen, W. P. (2013). Attitudes towards science, technology, engineering and mathematics (STEM) in a project-based learning (PjBL) environment. International Journal of Technology and Design Education, 23(1), 87-102.

[35] Yamak,H., Bulut, N., \& Dündar, S. (2014). 5. Sınıf Öğrencilerinin Bilimsel Süreç Becerileri ile Fene Karşı Tutumlarına FeTeMM Etkinliklerinin Etkisi. Gazi Üniversitesi Eğitim Fakültesi Dergisi, 344(2), 249-265.

[36] Gülhan, F., \& Şahin, F. (2018). STEAM (STEM+Sanat) etkinliklerinin 7. sınıf öğrencilerinin akademik başarı, STEAM tutum ve bilimsel yaratıcıliklarına etkisi. Journal of Human Sciences, 15(3), 1675-1699. 